\title{
UPLC/MS BASED PHYTOCHEMICAL SCREENING AND ANTIDIABETIC PROPERTIES OF PICRORHIZA KURROA IN MITIGATING GLUCOSE-INDUCED METABOLIC DYSREGULATION AND OXIDATIVE STRESS
}

\author{
MOHAMMAD IBRAHIM ${ }^{1,2}$, BUSHRA PARVEEN ${ }^{1,2}$, SULTAN ZAHIRUDDIN $^{1}$, RABEA \\ PARVEEN $^{1,4}$, MOHAMMED AHMAD KHAN $^{2}$, ARUN GUPTA $^{3}$, SAYEED AHMAD $^{1 *}$ \\ ${ }^{I}$ Bioactive Natural Product Laboratory, SPER, Jamia Hamdard, New Delhi, India \\ ${ }^{2}$ Department of Pharmacology, SPER, Jamia Hamdard, New Delhi, India \\ ${ }^{3}$ Department of Medical Affairs and Clinical Research, Dabur India Limited, Ghaziabad, U.P., India \\ ${ }^{4}$ Department of Biosciences, Jamia Millia Islamia, New Delhi, India \\ *corresponding author: sahmad_jh@yahoo.co.in
}

Manuscript received: November 2020

\begin{abstract}
Diabetes is a metabolic disorder increasing at an alarming rate in the current era. Medicinal plants and their supplements have shown protective effects against metabolic dysregulation and oxidative damage. The present study is aimed to explore the antidiabetic potential of hydroalcoholic extract of Picrorhiza kurroa (HAE-PK). The UPLC/MS analysis revealed 23 most abundant bioactive substances. HAE-PK exhibited significant $\alpha$-amylase and $\alpha$-glucosidase inhibitory activities with an $\mathrm{IC}_{50}$ value of $124.7 \pm 0.59$ and $135.03 \pm 1.28$, respectively, and paralleled with standard acarbose. It also contained a very high amount of phenols and flavonoids and exhibited potent free radical scavenging activity using the DPPH test. Further, HAEPK reinstated the glucose-induced increase in hepatocytic enzymes, aldehyde dehydrogenase (ALDH) and hexokinase. Further, HAE-PK significantly improved the glucose-induced cytotoxicity in $\mathrm{HepG}_{2}$ cells. Thus, we conclude that HAE-PK can be a considerable prospect in the management of hyperglycaemia, diabetes and related oxidative stress.
\end{abstract}

\section{Rezumat}

Diabetul este o tulburare metabolică ce evoluează alarmant în prezent. Plantele medicinale au arătat un efect protector împotriva dezechilibrelor metabolice și oxidative. Prezentul studiu are ca scop explorarea potenţialului antidiabetic al extractului hidroalcoolic de Picrorhiza kurroa (HAE-PK). Analiza UPLC/MS a evidențiat prezența a 23 de substanțe bioactive. HAE-PK a prezentat activități semnificative de inhibare a $\alpha$-amilazei și $\alpha$-glucozidazei cu o valoare $\mathrm{IC}_{50}$ de $124.7 \pm$ 0,59 și respectiv 135,03 $\pm 1,28$, comparativ cu acarboza. De asemenea, extractul conține o cantitate mare de compuşi fenolici și flavonoide și prezintă o activitate puternică de neutralizare a radicalilor liberi, evidențiată prin metoda DPPH. HAE-PK a echilibrat creșterea indusă de glucoză asupra enzimelor hepatice, aldehid dehidrogenaza (ALDH) şi hexokinaza. HAE-PK a îmbunătățit semnificativ citotoxicitatea indusă de glucoză în celulele $\mathrm{HepG}_{2}$. Astfel, se poate concluziona că HAE-PK prezintă perspective în managementul hiperglicemiei, diabetului şi al stresului oxidativ.

Keywords: diabetes, Picrorhiza kurroa, UPLC/MS, antioxidant, $\alpha$-amylase, $\alpha$-glucosidase

\section{Introduction}

Diabetes is a serious disease and have contributed tremendously to the burden of human health and world economies. According to IDB (International Diabetic Federation), 693 million people will be living with diabetes in 2045 [1]. Despite a significant progress made in the treatment of diabetes, the result is still far from expected [2]. Albeit, high prevalence, variable pathogenesis, progressive process, and complications of diabetes warrant urgent need for its effective management.

Over the years, it has been generally noticed that the consumption of local herbs and vegetables improve the human health, in terms of prevention, and/or cure of diseases [3]. The World Health Organisation (WHO) recommended exploring diverse arrays of biologically active compounds to develop newer antidiabetic leads [4]. Picrorhiza kurroa Royle ex Benth. (Scrophulariaceae family), is a familiar herb in the indigenous system of medicine known for its varied pharmacological actions [5]. Kumar et al., 2017 reported that $P$. kurroa displayed $\beta$-cell regeneration with enhanced insulin production and antihyperglycaemic effects by increasing the insulin-mediated translocation of GLUT4 from cytosol to plasma membrane, which results in a better glucose uptake by skeletal muscle cells and an improved glycaemic control in diabetes [6].

Virtually, the entire spectrum of metabolic dysfunctions seen in patients with diabetes include abnormal liver enzymes activity and generation of reactive oxygen 
species that reduces the defence system of the cells, eventually leading to diabetes [7]. Many drugs presently prescribed by physicians are either directly isolated from plants or artificially modified versions of natural products. However, the majority of the indigenous plants used as medicinal products scientifically validated for their safety and efficacy. Therefore, detailed and extended profiling of phytoconstituents is necessary to establish the quality of hydroalcoholic extract of $P$. kurroa and to explore the effects of glucose-induced hyperglycaemia in a hepatocellular carcinoma $\left(\mathrm{HepG}_{2}\right)$ cell line [8].

To the best of our knowledge, no previous scientific research has evaluated the efficacy of HAE-PK in glucose-induced hyperglycaemia and its cytotoxicity in hepatocytes. Therefore, the present research aims to the metabolomic profiling of HAE-PK and its potential in the glucose-induced hyperglycaemic in $\mathrm{HepG}_{2}$ cells.

\section{Materials and Methods}

Plant material: The fresh rhizome of $P$. kurroa was obtained from Dabur India Limited, India, as gift sample. The voucher specimen has been retained in laboratory with the no BNPL/MI/2018/PK01.

Extraction procedure: $50 \mathrm{~g}$ of coarsely powdered $P$. kurroa rhizome were extracted using $400 \mathrm{~mL}$ of solvent, ethanol:water $(1: 1)$, by refluxing on a water bath at $60^{\circ} \mathrm{C}$ for 3 hours after macerating it for 12 hours at room temperature, with occasional shaking. The mixture was filtered using Whatman filter paper no. 1, and the residue was washed with fresh solvent. The filtrate and washing solution were pooled and evaporated to dryness on a Rotavapor below $60^{\circ} \mathrm{C}$. The residue obtained was weighed and stored in wellclosed containers at $-20^{\circ} \mathrm{C}$ until used for analysis.

Ultra-performance liquid chromatography-tandem mass spectrometry (UPLC/MS) analysis of HAE-PK: Chromatographic analysis was performed on Acquity UPLC HSS C18 $(50 \times 2.1 \mathrm{~mm}, 1.8 \mathrm{~m})$ column using an isocratic mobile phase consisting of $0.1 \%$ formic acid (A) and methanol (B) at a flow rate of $0.6 \mathrm{~mL} /$ min. The separated metabolites were detected by MS. The separated compounds were identified based on their $m / z$ value through literature database.

Estimation of total phenolic and flavonoid content: Total phenolic and flavonoid content were determined by the method described by Parveen et al. [9]. Gallic acid and quercetin were used as a reference standard for the calibration curve. All the experiments were performed in triplicate.

$\alpha$-Amylase and $\alpha$-glucosidase inhibition assay: Activity of $\alpha$-amylase and $\alpha$-glucosidase, respectively were carried out as in the previously described method [10]. The results were expressed as \% inhibition of enzyme activity and calculated by the underneath equation:

Percentage Inhibition $=\left(\mathrm{A}_{\text {control }}-\mathrm{A}_{\text {sample }}\right) \times 100 / \mathrm{A}_{\text {control }}$, where, $\mathrm{A}_{\text {control }}=$ absorbance of control sample and $\mathrm{A}_{\text {sample }}=$ absorbance of test sample.

$D P P H$ radical scavenging assay: The DPPH radical scavenging activity was determined by the spectrophotometric method for the presence of DPPH as a free radical. All the experiments were performed in triplicate. The following equation has been used to calculate the percentage of DPPH scavenging activity [1]:

Percentage scavenging activity $=\left(1-\mathrm{A}_{\text {sample }} / \mathrm{A}_{\text {control }}\right) \times 100$, where, $\mathrm{A}_{\text {control }}=$ absorbance of control reaction containing methanol instead of sample and $\mathrm{A}_{\text {sample }}=$ absorbance of test sample.

Cell culture and treatment: $\mathrm{HepG}_{2}$ cell lines were purchased from NCSS, India. The study was performed as per the defined protocol.

Cytotoxicity effect of glucose and HAE-PK on $\mathrm{HepG}_{2}$ : The assay was performed using MTT dissolved in culture medium followed by filtering and incubation for 2 - $4 \mathrm{~h}$ to assess the cytotoxicity [12]. Presence of viable cells was visualized by the development of purple colour recorded at $595 \mathrm{~nm}$ using UV spectrophotometer against blank.

Measurement of cellular reactive oxygen species $\left(R O S^{*}\right)$ : Intracellular antioxidant measurements were made as in the previously described method [13] with little modifications.

Assessment of aldehyde dehydrogenase and hexokinase: The aldehyde dehydrogenase (ALDH) activity was estimated based on the reduction of $\beta$-NAD ( $\beta$ Nicotinamide adenine dinucleotide) while, the hexokinase activity was evaluated based on the reaction with glucose-6-phosphate dehydrogenase, respectively, as in the previously defined methods $[14,15]$.

\section{Results and Discussion}

UPLC/MS profiling of HAE-PK: HAE-PK was dissolved in methanol and UPLC/MS fingerprinting was performed for the identification of complete metabolites present in HAE-PK (Table I). Metabolites present in the HAE-PK are summarized with retention time, mass by charge $(\mathrm{m} / \mathrm{z})$ values, tentative name, nature of compound and chemical formula with respective literature IDs. A total of 23 most abundant metabolites were analysed and identified through $\mathrm{m} / \mathrm{z}$ value and from a literature survey. Previous literature strongly revealed that, glycosides (iridoid glycosides) present in HAE-PK possess excellent antidiabetic potential [6]. Picroside was observed as the most abundant metabolite in HAE-PK. Thus, for the analysis of metabolite profiling, UPLC/MS method seems to be the best method of analysis.

Phenolic and flavonoid content of HAE-PK: The total phenolic and flavonoid content of the HAE-PK were determined using standard calibration curve of gallic acid $\left(r^{2}=0.996\right)$ and quercetin $\left(r^{2}=0.992\right)$, respectively. The total phenolic and flavonoid content were found 
FARMACIA, 2021, Vol. 69, 4

to be $37.26 \pm 0.09 \mathrm{mg}$ gallic acid equivalent/g dry wt. of HAE-PK and $28.65 \pm 0.27 \mathrm{mg}$ quercetin equivalent/g dry wt. of HAE-PK, respectively. Our results, showed that the extract is enriched with phenols and flavonoids which may be responsible for the therapeutic potential. Also, biologically and pharmacologically it is known that phenolic and flavonoid rich nutraceuticals/food reduce the risk of diabetes [16].

Major metabolites detected in hydroalcoholic extract Picrorhiza kurroa (HAE-PK) by UPLC/

\begin{tabular}{|c|c|c|c|c|c|c|}
\hline $\begin{array}{c}\text { Metabolites } \\
\text { (M) }\end{array}$ & $\begin{array}{c}\mathbf{R t} \\
(\mathbf{m i n})\end{array}$ & $\begin{array}{c}\text { Name of } \\
\text { metabolites }\end{array}$ & $\begin{array}{c}\text { Class of } \\
\text { compounds }\end{array}$ & $\begin{array}{l}\text { References } \\
\text { (Mass ID) }\end{array}$ & $\begin{array}{c}\text { Molecular } \\
\text { formula }\end{array}$ & \begin{tabular}{|c|}
$(m / z$ \\
value $)$
\end{tabular} \\
\hline M1 & 0.850 & D-(-)-quinic acid & Alkaloid & PubChem: 6508 & $\mathrm{C}_{7} \mathrm{H}_{12} \mathrm{O}_{6}$ & 192.16 \\
\hline M2 & 2.211 & Kutkin & Glycoside & PubChem: 131750182 & $\mathrm{C}_{23} \mathrm{H}_{28} \mathrm{O}_{12}$ & 496.46 \\
\hline M3 & 3.028 & Ergosine & Alkaloid & PubChem: 105137 & $\mathrm{C}_{30} \mathrm{H}_{37} \mathrm{~N}_{5} \mathrm{O}_{5}$ & 547.65 \\
\hline M4 & 3.198 & Picroside-II & Glycoside & PubChem: 11944602 & $\mathrm{C}_{23} \mathrm{H}_{28} \mathrm{O}_{13}$ & 512.46 \\
\hline M5 & 3.674 & (-)-epigallocatechin & Flavonoid & PubChem: 72277 & $\mathrm{C}_{15} \mathrm{H}_{14} \mathrm{O}_{7}$ & 306.27 \\
\hline M6 & 4.388 & p-hydroxy benzoic acid & Phenol & PubChem: 135 & $\mathrm{C}_{7} \mathrm{H}_{6} \mathrm{O}_{3}$ & 138.12 \\
\hline M7 & 4.695 & Caffeic acid & Phenol & PubChem: 689043 & $\mathrm{C}_{9} \mathrm{H}_{8} \mathrm{O}_{4}$ & 180.15 \\
\hline M8 & 5.307 & Picroside IV & Glycoside & ChemBook: 61339879 & $\mathrm{C}_{24} \mathrm{H}_{28} \mathrm{O}_{12}$ & 508.17 \\
\hline M9 & 6.396 & Pikuroside & Glycoside & PubChem: 132472101 & $\mathrm{C}_{23} \mathrm{H}_{30} \mathrm{O}_{14}$ & 530.47 \\
\hline M10 & 7.620 & Isocorilagin & Phenol & PubChem: 10077799 & $\mathrm{C}_{27} \mathrm{H}_{22} \mathrm{O}_{18}$ & 634.45 \\
\hline M11 & 7.893 & Cinchonine & Alkaloid & PubChem: 90454 & $\mathrm{C}_{19} \mathrm{H}_{22} \mathrm{~N}_{2} \mathrm{O}$ & 293.37 \\
\hline M12 & \begin{tabular}{|l|}
8.879 \\
\end{tabular} & Linoleic acid & Fatty acid & PubChem: 5280450 & $\mathrm{C}_{18} \mathrm{H}_{32} \mathrm{O}_{2}$ & 280.45 \\
\hline M13 & 9.287 & Veronicoside & Glycoside & PubChem: 329824805 & $\mathrm{C}_{22} \mathrm{H}_{26} \mathrm{O}_{11}$ & 466.44 \\
\hline M14 & 10.410 & Catalpol & Glycoside & PubChem: 91520 & $\mathrm{C}_{15} \mathrm{H}_{22} \mathrm{O}_{10}$ & 362.33 \\
\hline M15 & 10.954 & 3',6-dimethyl-flavone & Flavonoid & PubChem: 688822 & $\mathrm{C}_{17} \mathrm{H}_{14} \mathrm{O}_{2}$ & 250.29 \\
\hline M16 & 11.703 & Ellagic acid & Phenol & PubChem: 5281855 & $\mathrm{C}_{14} \mathrm{H}_{6} \mathrm{O}_{8}$ & 302.19 \\
\hline M17 & 12.757 & (-)-specioside & Glycoside & PubChem: 44566579 & $\mathrm{C}_{23} \mathrm{H}_{28} \mathrm{O}_{11}$ & 480.46 \\
\hline M18 & 13.030 & Brevianamide $\mathrm{A}$ & Alkaloid & PubChem: 99771 & $\mathrm{C}_{21} \mathrm{H}_{23} \mathrm{~N}_{3} \mathrm{O}_{3}$ & 365.43 \\
\hline M18 & 13.710 & Papaveraldine & Alkaloid & PubChem: 96932 & $\mathrm{C}_{20} \mathrm{H}_{19} \mathrm{NO}_{5}$ & 353.37 \\
\hline M19 & 14.4256 & 6-ethoxy-3(4'-hydroxyphenyl)-4-methylcoumarin & Phenol & ChemSpider: 600190 & $\mathrm{C}_{18} \mathrm{H}_{16} \mathrm{O}_{4}$ & 296.31 \\
\hline M20 & 15.411 & beta-hydrastine & Alkaloid & PubChem: 197835 & $\mathrm{C}_{21} \mathrm{H}_{21} \mathrm{NO}_{6}$ & 383.40 \\
\hline M21 & 17.214 & 2-coumaric acid & Phenol & PubChem: 637540 & $\mathrm{C}_{9} \mathrm{H}_{8} \mathrm{O}_{3}$ & 164.16 \\
\hline M22 & 17.384 & Gelsenicine & Alkaloid & PubChem: 21123652 & $\mathrm{C}_{19} \mathrm{H}_{22} \mathrm{~N}_{2} \mathrm{O}_{3}$ & 326.39 \\
\hline M23 & 17.895 & Aucubin & Glycoside & PubChem: 91458 & $\mathrm{C}_{15} \mathrm{H}_{22} \mathrm{O}_{9}$ & 346.33 \\
\hline
\end{tabular}

$\alpha$-Amylase and $\alpha$-glucosidase inhibitory activities of $H A E-P K$ : The $\mathrm{IC}_{50}$ values of HAE-PK showed potential inhibitory effects on $\alpha$-amylase and $\alpha$-glucosidase as compared to the standard antidiabetic compound, acarbose (Table II). The inhibitory potential of HAE-PK directly reduces the breakdown of starch to smaller molecules of oligosaccharides in to the gastrointestinal tract and subsequently reduces the glucose absorption. This may also lead to a reduction in postprandial hyper-glycaemia levels. $\alpha$-glucosidase, located in brush borders of small intestines, hydrolyses the oligosaccharides and cleave the glycoside bonds to liberate glucose from the nonreducing end of oligosaccharide and polysaccharide chains [17]. Hence, inhibition of $\alpha$-amylase and $\alpha$ glucosidase is a very effective way of delaying glucose absorption and lowering the postprandial blood glucose level, which can potentially suppress the progression of diabetes.

DPPH antioxidant activity: 1,1-Diphenyl-2-picrylhydrazyl (DPPH) assay is widely used to determine the antioxidant activity of single compounds and plant extracts. Results of the present study revealed that HAE-PK shows significant inhibitory potential in dosedependent manner on DPPH free radical at tested concentrations $(25-250 \mu \mathrm{g} / \mathrm{mL})$. $\mathrm{IC}_{50}$ values of HAE$\mathrm{PK}$ and quercetin were recorded as $88.44 \pm 0.42$ and $71.54 \pm 0.64 \mu \mathrm{g} / \mathrm{mL}$ (Table II). Recent evidence suggests that oxidative stress may contribute to the pathogenesis of diabetes. The diet, especially natural products or food supplements, contain a vast number of compounds with antioxidant activity, which may have cumulative/synergistic antioxidant effects [18].

Table II

Antidiabetic and antioxidant potential of HAE-PK

\begin{tabular}{|c|c|c|c|c|c|}
\hline \multicolumn{4}{|c|}{ Antidiabetic Potential $\left(\right.$ IC $_{\mathbf{5 0}}$ ) } & \multicolumn{2}{c|}{ Antioxidant Potential (IC ( $_{\mathbf{5 0}}$ ) } \\
\hline \multicolumn{2}{|c|}{$\alpha$-Amylase } & \multicolumn{2}{c|}{$\alpha$-Glucosidase } & \multicolumn{2}{c|}{ DPPH } \\
\hline Acarbose & HAE-PK & Acarbose & HAE-PK & Quercetin & HAE-PK \\
\hline $164.7+.81$ & $124.7+0.59$ & $164.7+1.09$ & $135.03+1.28$ & $71.54+0.64$ & $88.44+0.42$ \\
\hline
\end{tabular}


Characterization of time course and dose-dependent toxicity of glucose and $\mathrm{HAE}-\mathrm{PK}$ in $\mathrm{HepG}_{2}$ cells: Results obtained from the cytotoxicity assay revealed that 5 and $25 \mathrm{mM}$ glucose did not cause any significant toxicity to $\mathrm{HepG}_{2}$ cells at $24 \mathrm{hrs}$ and $48 \mathrm{hrs}$, and throughout the study, cell viability was maintained up to $90.5 \pm$ $2.67 \%$ and $88.79 \pm 1.70 \%$, respectively. Further, treatment of $\mathrm{HepG}_{2}$ cells with $50 \mathrm{mM}$ glucose for 24 - $48 \mathrm{hrs}$ significantly affected the viability of $\mathrm{HepG}_{2}$ cells as compared to 5 and $25 \mathrm{mM}$ of glucose and cell viability decreased to $71.36 \pm 2.89 \%$ and $74.42 \pm 3.24 \%$, respectively (Figures $1 \mathrm{a}$ and $1 \mathrm{~b}$ ). In order to assess the nontoxic concentrations of HAEPK for the cytoprotective studies, we carried out the MTT based cytotoxicity assay in $\mathrm{HepG}_{2}$ cells for 24 and $48 \mathrm{hrs}$, respectively. HAE-PK did not cause any toxicity to the $\mathrm{HepG}_{2}$ cells up to $500 \mu \mathrm{g} / \mathrm{mL}$, and cell viability was maintained at about $92-97 \%$ throughout the study (Figures $2 \mathrm{a}$ and $2 \mathrm{~b}$ ). Further, treatment with
HAE-PK $(250 \mu \mathrm{g} / \mathrm{mL})$ led to an enhanced cell viability in high glucose-induced $\mathrm{HepG}_{2}$ cells for 24 - $48 \mathrm{hrs}$ (Figures $3 \mathrm{a}$ and $3 \mathrm{~b}$ ). However, $50 \mathrm{mM}$ glucose was used to replicate hyperglycaemia in $\mathrm{HepG}_{2}$ cells.

Previous studies describe that high glucose induces oxidative stress and disturbs the normal physiology of the cell by damaging the cellular integrity. Protection of cellular physiology is of prime importance in order to counteract the hyperglycaemia-induced oxidative damage. Kong et al. described that cytotoxicity or the cytoprotective effect of the plant extracts is highly dependent on their concentration, bioavailability and complex interactions among phytochemicals [19]. However, current results strongly suggest that HAEPK can maintain cell growth and physiological functions against glucose-induced hyperglycaemia and oxidative stress state and is only cytotoxic at very high concentrations.
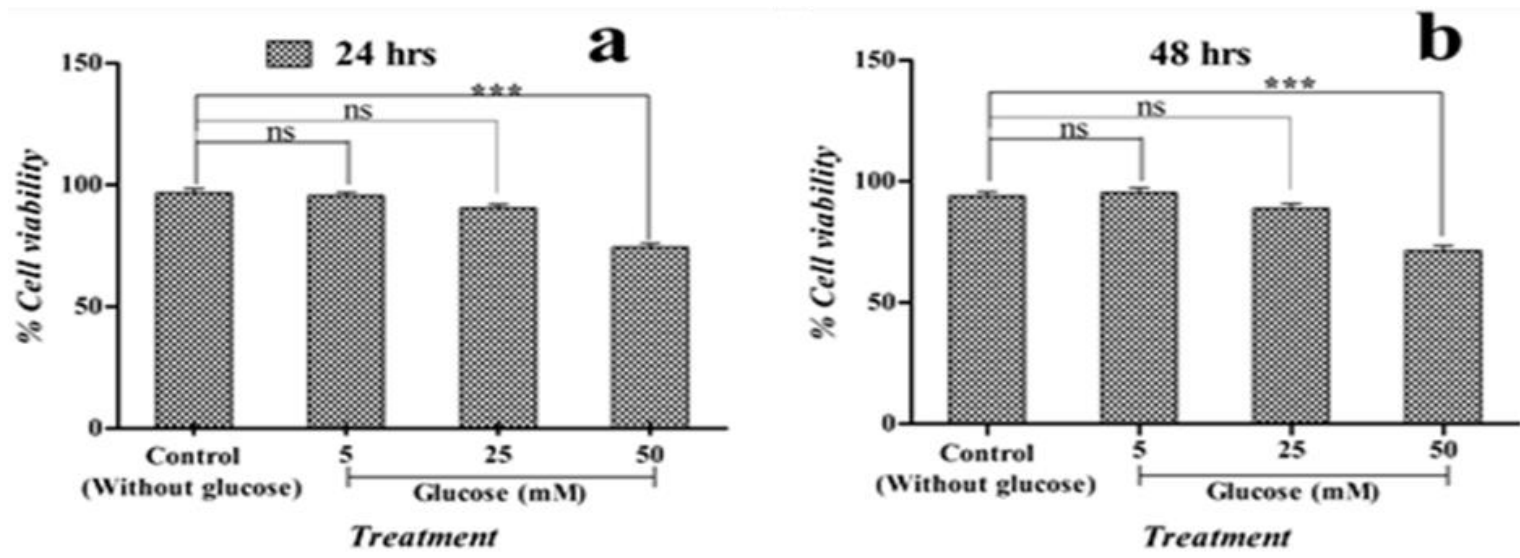

Figure 1.

Time and concentration dependent effects of glucose on viability of $\mathrm{HepG}_{2}$ cells. The values are expressed as mean \pm SD of triplicate tests as determined by ANOVA $(* \mathrm{p}<0.05, * * \mathrm{p}<0.01$ and $* * * \mathrm{p}<0.001)$ p-value compared with untreated (control) $\mathrm{HepG}_{2}$ cells
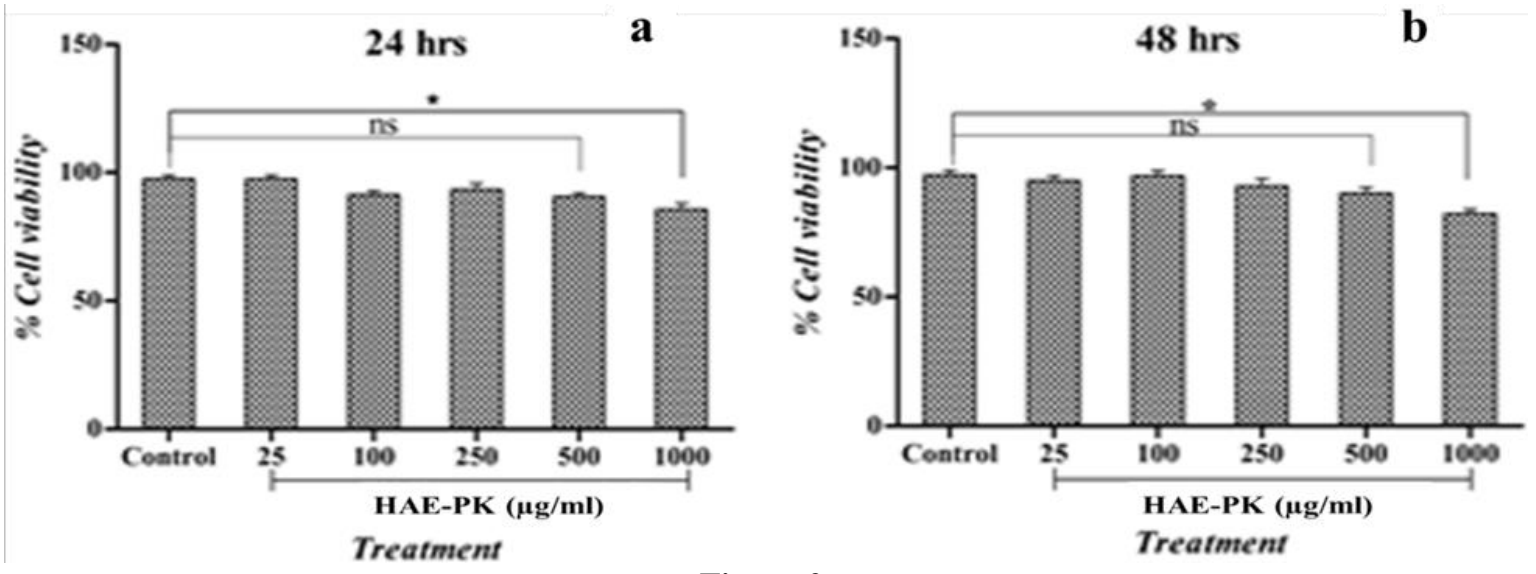

Figure 2.

Time and concentration dependent effects of HAE-PK on viability of $\mathrm{HepG}_{2}$ cells. The values are expressed as mean $\pm \mathrm{SD}$ of triplicate tests as determined by ANOVA $(* \mathrm{p}<0.05$, ** $<<0.01$ and $* * * \mathrm{p}<0.001)$. p-value compared with untreated (control) $\mathrm{HepG}_{2}$ cells 


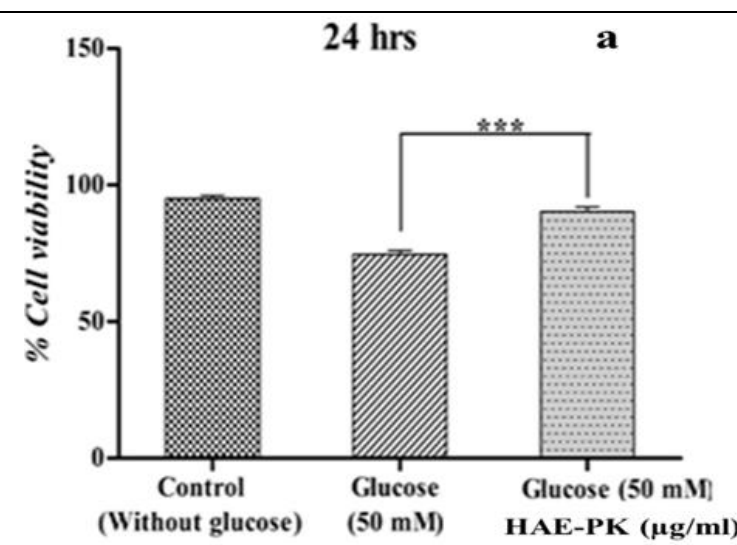

Treatment

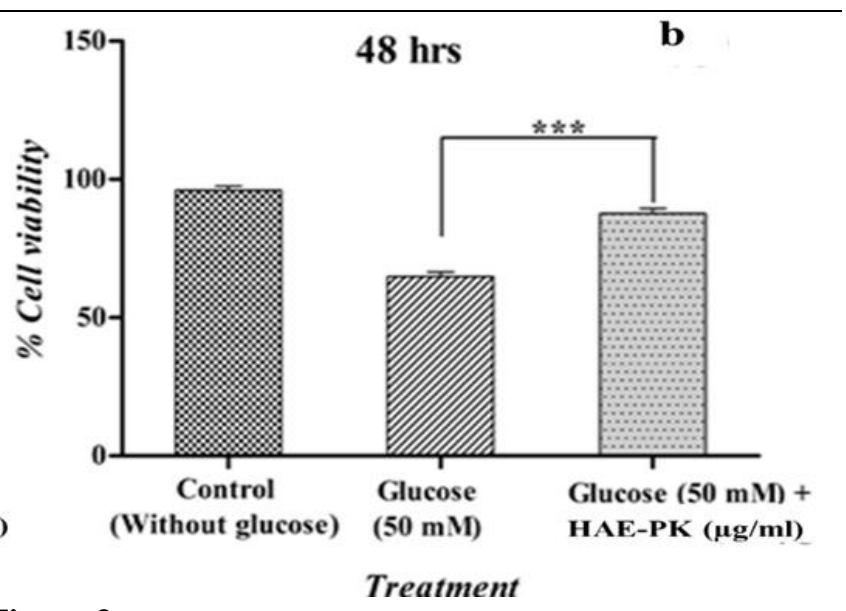

Figure 3.

Time dependent effects of HAE-PK on viability of $\mathrm{HepG}_{2}$ cells against glucose induce hyperglycaemia. The values are expressed as mean $\pm \mathrm{SD}$ of triplicate tests as determined by ANOVA $\left(*_{\mathrm{p}}<0.05\right.$, ** $\mathrm{p}<0.01$ and $* * * \mathrm{p}<0.001)$. p-value compared with glucose-induced hyperglycaemia on $\mathrm{HepG}_{2}$ cells

Effect of HAE-PK on glucose-induced ALDH and hexokinase expression in $\mathrm{Hep}_{2}$ cells: A significant increase in ALDH activity was found in hyperglycaemic treatment group in $\mathrm{HepG}_{2}$ cells for 24 and $48 \mathrm{hrs}$, respectively as compared to normal. While, after treatment with HAE-PK $(250 \mu \mathrm{g} / \mathrm{mL})$, the level of ALDH was $(* * * p<0.001$ and **p $<0.01)$ restored to normal (Figures $4 \mathrm{a}$ and $4 \mathrm{~b}$ ). Liver is a metabolic crossroad, crucial for glucose metabolism in animals, for the regulation of the systemic fuel and cellular functions. Increased sugar consumption is considered to be one of contributors to the worldwide epidemics of obesity and diabetes and their associated cardiometabolic risks. Because of its unique metabolic properties, the glucose and fructose component of sugar may be particularly harmful for the normal metabolic function of the liver. Altered metabolism of glucose or fructose in liver are the backbone of triglyceride synthesis [20].
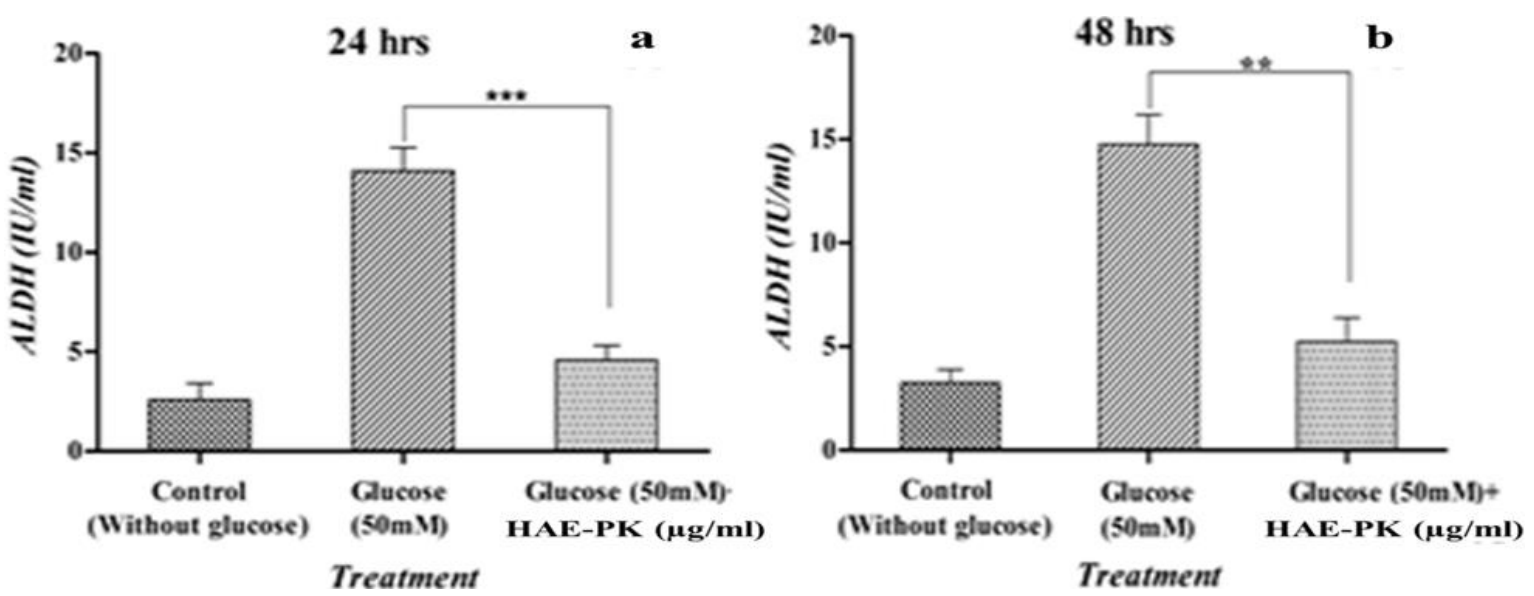

Figure 4.

Time dependent effects of HAE-PK $(250 \mu \mathrm{g} / \mathrm{mL})$ on level of ALDH in hyperglycaemia (glucose $50 \mathrm{mM}$ ) induced $\mathrm{HepG}_{2}$ cells for a) $24 \mathrm{hrs}$ and b) $48 \mathrm{hrs}$. The values are expressed as mean $\pm \mathrm{SD}$ of triplicate tests as determined by ANOVA $(* \mathrm{p}<0.05, * * \mathrm{p}<0.01$ and $* * * \mathrm{p}<0.001)$. p-value compared with group hyperglycaemia (glucose $50 \mathrm{mM}$ ) $\mathrm{HepG}_{2}$ cells

In case of hexokinase activity, the level of hexokinase sharply blunted in hyperglycaemic groups for $24-48$ hrs, as compared to control (Figures 5a and 5b). After treatment with HAE-PK $(250 \mu \mathrm{g} / \mathrm{mL})$, the hexokinase level was significantly $(* * \mathrm{p}<0.01$ and $* \mathrm{p}<0.05$ ) brought to normal. Hexokinase is the first key enzyme which catalyses the first committed step in glucose metabolism by phosphorylating glucose to glucose-6- phosphate (G6P) in the glycolytic pathway. Recent studies have indicated that aberrant hexokinase activity is associated with many human diseases, such as diabetes, muscular dystrophy and cancer [21]. A study by Rabbani and Thornalley, described that in hyperglycaemic state, increased level of hexokinase and G6P initiate metabolic dysfunction leading to tissue damage. The hypothesis of hexokinase linked glycolytic 
overload provides an explanation of pathogenic mechanisms and experimental observations associated with the development of vascular complications of diabetes and prediabetes, diabetic embryopathy and tissue progenitor cell dysfunction in diabetes. It may be postulated that hexokinase receptor is a therapeutically competent target to maintain the physiological function of the cells and inhibit the disease progression due to high concentrations of glucose [22].
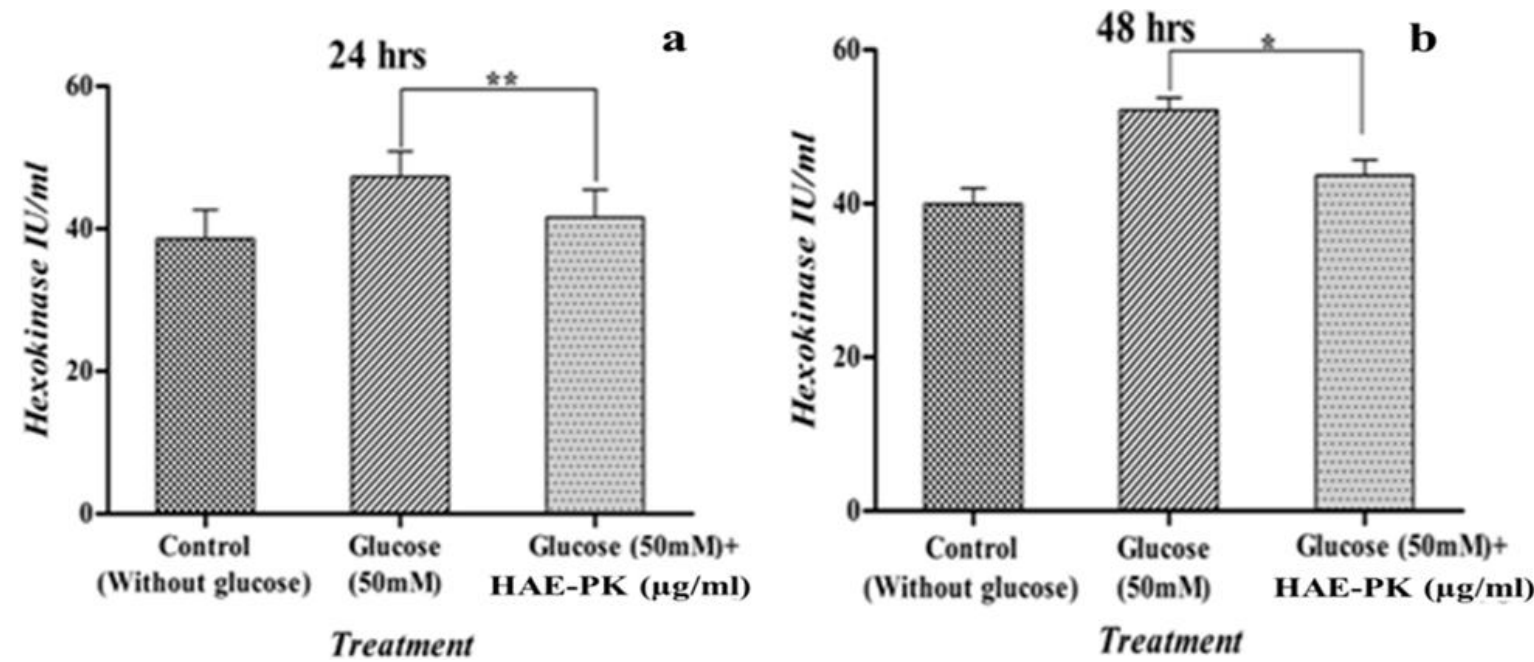

Treatment

Figure 5.

Time dependent effects of HAE-PK $(250 \mu \mathrm{g} / \mathrm{mL})$ on level of hexokinase against hyperglycaemia (glucose 50 $\mathrm{mM}$ ) induced in $\mathrm{HepG}_{2}$ cells for a) $24 \mathrm{hrs}$ and b) $48 \mathrm{hrs}$. The values are expressed as mean \pm SD of triplicate tests as determined by ANOVA $(* \mathrm{p}<0.05, * * \mathrm{p}<0.01$ and $* * * \mathrm{p}<0.001)$. p-value compared with group hyperglycaemia (glucose $50 \mathrm{mM}$ ) $\mathrm{HepG}_{2}$ cells

A significant increase in the level of ALDH and hexokinase in glucose-induced hyperglycaemia substantiated the hepatic damage/oxidative stress whereas, HAEPK significantly reversed the level of ALDH and hexokinase against hyperglycaemia. The extract may regulate the activities of these enzymes in diabetes through either normalizing the glycolysis or increasing the utilization of glucose for energy production. In a previous investigation, coumarin and citral markedly reduced hyperglycaemia in diabetes by regulating the oxidative stress and hepatic metabolism [23]. This could be due to the activity of the extract in maintaining metabolic regulation, as evidenced by changes in the levels of biochemical parameters (ALDH and hexokinase) linked to different metabolic pathways. With such evidence, it is conceivable to propose that HAEPK exhibits its antidiabetic effect in $\mathrm{HepG}_{2}$ cell line by maintaining the hepatic key enzymes involved in the carbohydrate metabolism.

\section{Conclusions}

Our findings clearly demonstrated that HAE-PK inhibits the enzymes $\alpha$-amylase and $\alpha$-glucosidase as well as restores the level of the studied metabolic enzymes. ALDH and hexokinase, linked to diabetes, thus endorsing a great potential for its use in the prevention and treatment of diabetes. UPLC/MS profiling of HAEPK showed the presence of different phytochemicals including alkaloids, glycosides, phenols and flavonoids etc. Hence, the observed antidiabetic activity may be the combined effect of all or either of these constituents. However, the future prospective use of HAE-PK in the treatment of diabetes warrants further exhaustive in silico, experimental and clinical studies to determine the exact mechanism of action of its bioactive principles. However, it can be attributed to an overall multi-component, multi-mechanistic synergistic action of flavonoids, phenols and iridoids.

\section{Conflict of interest}

The authors declare no conflict of interest.

\section{References}

1. International Diabetic Federation, 2017. Diabetes atlas. $8^{\text {th }}$ edition.

2. Marín-Peñalver JJ, Martín-Timón I, Sevillano-Collantes C, Del Cañizo-Gómez FJ, Update on the treatment of type 2 diabetes mellitus. World J Diabetes, 2016; 7(17): 354-395.

3. Uboh FE, Okon IE, Ekong MB, Effect of aqueous extract of Psidium guajava leaves on liver enzymes, histological integrity and hematological indices in rats. Gastroenterology Res., 2010; 3(1): 32-38.

4. Wang Z, Wang J, Chan P, Treating type 2 diabetes mellitus with traditional Chinese and Indian medicinal herbs. Evid Based Complement Alternat Med., 2013; 2013: 343594: 1-17.

5. Mallick MN, Singh M, Parveen R, Khan W, Ahmad S, Najm MZ, Husain SA, HPTLC analysis of bioactivity guided anticancer enriched fraction of hydroalcoholic 
extract of Picrorhiza kurroa. BioMed Res Int., 2015; 2015: 513875: 1-18

6. Kumar S, Patial V, Soni S, Sharma S, Pratap K, Kumar D, Padwad Y, Picrorhiza kurroa enhances $\beta$-Cell mass proliferation and insulin secretion in streptozotocin evoked $\beta$-Cell damage in rats. Front Pharmacol., 2017; 8: 537: 1-15.

7. Petersen MC, Shulman GI, Mechanisms of insulin action and insulin resistance. Physiol Rev., 2018; 98(4): 2133-2223

8. Sefried S, Häring H, Weigert C, Eckstein SS, Suitability of hepatocyte cell lines HepG2, AML12 and THLE-2 for investigation of insulin signalling and hepatokine gene expression. Open Biol., 2018; 8(10): 18047: $1-11$.

9. Parveen S, Ansari MHR, Parveen R, Khan W, Ahmad S, Husain SA, Chromatography based metabolomics and in silico screening of Gymnema sylvestre leaf extract for its antidiabetic potential. Evid Based Complement Alternat Med., 2019; 2019: 7523159: 1-14.

10. Khan W, Parveen R, Chester K, Parveen S, Ahmad S, Hypoglycemic Potential of aqueous extract of Moringa oleifera leaf and in vivo GC-MS Metabolomics. Front Pharmacol., 2017; 8: 577: 1-16.

11. Chester K, Paliwal S, Khan W, Ahmad S, UPLCESI-MS/MS and HPTLC method for quantitative estimation of cytotoxic glycosides and aglycone in bioactivity guided fractions of Solanum nigrum L. Front Pharmacol., 2017; 8: 434: 1-15.

12. Senthilraja $\mathrm{P}$, Kathiresan $\mathrm{K}$, In vitro cytotoxicity MTT assay in vero, HepG2 and MCF-7 cell lines study of marine yeast. J Appl Pharm Sci., 2015; 5(03): 80-84.

13. Subramaniyan SD, Natarajan AK, Citral, a monoterpene protects against high glucose induced oxidative injury in HepG2 cell in vitro-an experimental study. J Clin Diagn Res., 2017; 11(8): BC10-BC15.

14. Bostian KA, Betts GF, Kinetics and reaction mechanism of potassium-activated aldehyde dehydrogenase from Saccharomyces cerevisiae. Biochem J., 1978; 173(3), 787-798.
15. Brandstrup N, Kirk JE, Bruni C, The hexokinase and phosphoglucoisomerase activities of aortic and pulmonary artery tissue in individuals of various ages. J Gerontol., 1957; 12(2): 166-171.

16. Testa R, Bonfigli AR, Genovese S, De Nigris V, Ceriello A, The possible role of flavonoids in the prevention of diabetic complications. Nutrients, 2016; 8(5): 310: 1-13.

17. Agatonovic-Kustrin S, Morton DW, High-performance thin-layer chromatography HPTLC-direct bioautography as a method of choice for alpha-amylase and antioxidant activity evaluation in marine algae. J Chromatogr A., 2017; 29: 1530: 197-203.

18. Mancini FR, Affret A, Dow C, Balkau B, Bonnet F, Boutron-Ruault MC, Fagherazzi G, Dietary antioxidant capacity and risk of type 2 diabetes in the large prospective E3N-EPIC cohort. Diabetologia, 2018; 61(2): 308-316.

19. Kong KW, Mat-Junit S, Aminudin N, Hassan FA, Ismail A, Aziz AA, Protective effects of the extracts of Barringtonia racemosa shoots against oxidative damage in HepG2 cells. PeerJ., 2016; 4: e1628: 1-20.

20. Hannou SA, Haslam DE, McKeown NM, Herman MA, Fructose metabolism and metabolic disease. $J$ Clin Invest., 2018; 128(2): 545-555.

21. DeWaal D, Nogueira V, Terry AR, Patra KC, Jeon M, Guzman G, Au J, Long CP, Antoniewicz MR, Hay N, Hexokinase-2 depletion inhibits glycolysis and induces oxidative phosphorylation in hepatocellular carcinoma and sensitizes to metformin. Nat Commun., 2018; 9(1): 446: 1-14.

22. Rabbani N, Thornalley PJ, Hexokinase-2 glycolytic overload in diabetes and ischemia-reperfusion injury. Trends Endocrinol Metab., 2019; 30(7): 419-431.

23. Yao Y, Zhao X, Xin J, Wu Y, Li H, Coumarins improved type 2 diabetes induced by high-fat diet and streptozotocin in mice via antioxidation. Can J Physiol Pharmacol., 2018; 96(8): 765-771. 